\title{
Feasibility study of biogas upgrading coupled with nutrient removal from anaerobic effluents using microalgae-based processes
}

E. Posadas ${ }^{1}$, D. Szpak ${ }^{1}$, F. Lombó ${ }^{2}$ A. Domínguez ${ }^{3}$, I. Díaz ${ }^{3}$, S. Blanco ${ }^{4}$, P.A. García-Encina ${ }^{1}$, R. Muñoz ${ }^{1 *}$

1.-Department of Chemical Engineering and Environmental Technology, University of Valladolid, Dr. Mergelina s/n. 47005, Valladolid (Spain), Phone: +34983186424; Fax: +34983184865.

2- IUOPA Research Unit "Biotechnology and Experimental Therapy based on Nutraceuticals- BITTEN". Área de Microbiología. Departamento de Biología Funcional. Facultad de Medicina. Universidad de Oviedo. C/Julián Clavería, s/n. ES- 33006- Spain.

3- BIOGAS FUEL CELL S.A., Parque Tecnológico de Gijón, C\Luis Moya 82, Edificio Pisa $1^{\circ}$ izq, 33203 Gijón (Spain), Phone: +34984292020.

4- Department of Biodiversity and Environmental Management, University of León, 24071 León (Spain), Phone: +34987293139; Fax: +34987291563; (Current address: The Institute of the Environment. La Serna, 58, 24007 Leon, Spain).

*Corresponding author: mutora@iq.uva.es

\section{ACKNOWLEGEMENTS}

This research was supported by Biogas Fuel Cell S.A and the Regional Government of Castilla y León (Project GR76, VA024U14 and RTA2013-00056-C03-02). A. Crespo, S. Santamarta, S. Arranz, J.M. Bueno, C. Mongil and G. Villamizar are gratefully acknowledged for their practical assistance.

\begin{abstract}
The present research was conducted in order to simultaneously optimize biogas upgrading and carbon and nutrient removal from centrates in a $180 \mathrm{~L}$ high rate algal pond interconnected to an external $\mathrm{CO}_{2}$ absorption unit. Different biogas and centrate supply strategies were assessed in order to increase biomass lipid content. Results showed $99 \% \mathrm{CO}_{2}$ removal efficiencies from simulated biogas at liquid recirculation rates in the absorption column of $9.9 \mathrm{~m}^{3} \mathrm{~m}^{-2} \mathrm{~h}^{-1}$, concomitant with nitrogen and phosphorus removal efficiencies of $100 \%$ and $82 \%$, respectively, using a 1:70 diluted centrate at a hydraulic retention time of 7 days. The lipid content of the harvested algal-bacterial biomass remained low (2.9-11.2\%) regardless of the operational conditions, with no particular trend over the time. The good settling characteristics of the algal-bacterial flocs resulted in harvesting efficiencies over 95\%, which represented a cost-effective alternative for algal biomass reutilization compared to conventional physical-chemical techniques. Finally, high microalgae biodiversity was found regardless of the operational conditions.
\end{abstract}


Keywords: algal-bacterial symbiosis; biogas upgrading; biological wastewater treatment; microalgae lipid content; microalgae population dynamics.

\section{Introduction}

In the current global environmental and energy scenario, biogas upgrading coupled with nutrient removal from wastewaters in algal-bacterial photobioreactors constitutes a sustainable and promising alternative to conventional physical-chemical upgrading technologies (Bahr et al. 2014). This environmentally friendly and low energy demanding technology is based on the solar-powered photosynthetic fixation of $\mathrm{CO}_{2}$ from biogas by microalgae. The in situ produced photosynthetic $\mathrm{O}_{2}$ can be further utilized by sulfur oxidizing bacteria to oxidize the $\mathrm{H}_{2} \mathrm{~S}$ absorbed from biogas to $\mathrm{SO}_{4}{ }^{2-}$, and by heterotrophic and nitrifying bacteria to oxidize the organic matter and nitrogen present in wastewaters to $\mathrm{CO}_{2}$ and $\mathrm{NO}_{3}{ }^{-}$, respectively (Bahr et al. 2014; Muñoz and Guieysse 2006).

On the other hand, the current high price of fossil fuels, together with their irreversible depletion and accumulation of greenhouse gases derived from their combustion, are nowadays promoting an intensive research on biofuels from sustainable biomass sources (Chisti 2007; Christenson and Sims 2011). First and second generation biodiesel entails severe limitations such as an extensive use of land (competing with human food crops) and costly pretreatments, respectively (Alam et al. 2012). In this context, biodiesel from microalgae constitutes a third generation biofuel able to overcome the above mentioned environmental and ethic limitations based on the high productivity of microalgal cultures, the possibility of using a low-quality water and the lack of competition with crop land (Acién et al. 2012). Biodiesel from microalgae is obtained from the transesterification of their lipids, whose content can range from 5 to $77 \%$ (on a dry weight basis) depending on the microalgal species and cultivation conditions (Chisti 2007). The high current cost monoalgal biomass cultivation (from 4.2 to $12.6 € \mathrm{Kg}^{-1}$ in $2010-2011$ ) makes biodiesel from axenic microalgae non-competitive with conventional biodiesels, which requires a significant decrease in the biomass production costs (Acién et al. 2012; Norsker et al. 2011). The microalgae produced during the simultaneous upgrading of biogas and wastewater treatment constitutes a low cost and sustainable biomass feedstock for biodiesel production, since no fossil fuels-derived $\mathrm{CO}_{2}$ is used (Acién et al. 2012; Bahr et al. 2014). High rate algal ponds (HRAPs) represent the most versatile and cost-effective photobioreactor platform for the simultaneous treatment of wastewater and upgrading of biogas (Bahr et al. 2014; Park et al. 2011). Unfortunately, this open photobioreactor configuration often undergoes contamination by native algae or zooplankton when sensitive microalgae are cultivated (De Godos et al. 2009; García et al. 2000; Park et al. 2011). Therefore, the year round predominance of lipidrich microalgae in HRAPs seems unlikely based on the limited microalgae growth rates under lipid accumulation conditions (Breuer et al. 2012). In this context, nutrient deprivation has been shown as one of the most efficient strategies to induce storage lipid accumulation (Devi et al. 2013).

Despite the recent interest and intensive research conducted worldwide on microalgae cultivation as a promising technology for biofuel production, $\mathrm{CO}_{2}$ mitigation and wastewater treatment, the number of experimental studies evaluating the performance of such an integrated process is scarce (Park et al. 2011; Serejo et al., 2015; Posadas et al., 2015). Thus, the main emphasis has been on pilot scale experiments focusing on biogas upgrading and wastewater treatment (Bahr et al., 2014; Heubeck et al., 2007). Serejo 
et al. (2015) also evaluated the influence of the operational conditions in the chemical composition of the harvested biomass during the simultaneous biogas upgrading and wastewater treatment. In this study, we used a pilot-scale HRAP treating diluted wastewater centrate (the liquid fraction from the centrifugation of sludge digestate in sewage treatment plant) and $\mathrm{CO}_{2}$ from biogas. $\mathrm{CO}_{2}$ uptake was optimized under nutrient deprivation to enhance microalgae lipid accumulation. In addition, a morphological characterization of the microalgae assemblages was conducted.

\section{Materials and methods}

\section{Microorganisms and culture conditions}

The HRAP was initially filled with $0.75 \mathrm{~g} \mathrm{TSS} \mathrm{L}^{-1}$ of a consortium of microalgae/cyanobacteria (henceforth referred to as microalgae) and bacteria treating diluted centrates (1:7) in a similar HRAP. The microalgae inoculum composition was (\% of cells): Microspora sp. (53.5\%), Scenedesmus (27.8\%), Synechocystis aquatilis $(13.9 \%)$ and Woronichinia sp. (4.7\%). This microalgae population was selected based on its previous acclimation to the characteristics of the diluted wastewater. The population composition changed significantly over time (Tables S1-S7 Supplementary material).

\section{Simulated biogas and centrate}

The simulated biogas used was composed of $\mathrm{CO}_{2}(30 \%)$ and $\mathrm{N}_{2}(70 \%)$ instead of $\mathrm{CH}_{4}$ in order to avoid any explosion hazards (Abello Linde, Spain). $\mathrm{H}_{2} \mathrm{~S}$ was not included, because of its complete removal reported by Serejo et al. (2015) regardless of the operational conditions. Centrate wastewater, which is characterized by a low biodegradable fraction and a high concentration of nutrients (Bahr et al., 2014; Posadas et al., 2013), was obtained from the digested sludge-concentrating centrifuges at Valladolid wastewater treatment plant (WWTP) (Spain) and stored at $4{ }^{\circ} \mathrm{C}$ prior to use. Centrate was diluted with tap water prior to feeding the HRAP in order to avoid microalgae inhibition due to its high $\mathrm{NH}_{4}^{+}$ concentrations and to control nutrient supply while compensating water evaporation losses (Table 1) (González et al. 2008). In a real case scenario, the use of the HRAP effluent (depleted from nutrients) as dilution water would significantly increase the economic and environmental sustainability of the process.

\section{Table 1}

\section{Experimental set-up}

The experimental set-up consisted of a $15 \mathrm{~cm}$ deep $180 \mathrm{~L}$ HRAP, with an illuminated surface of $1.33 \mathrm{~m}^{2}$ (202 cm length $\times 63 \mathrm{~cm}$ width) and two water channels divided by a central wall, interconnected to a 2.5 $\mathrm{L}(\varnothing=4 \mathrm{~cm}$; height $=195 \mathrm{~cm})$ external $\mathrm{CO}_{2}$ absorption column $\left(\mathrm{CO}_{2}-\mathrm{AC}\right)$ via microalgae broth external recirculation (Fig. 1). The $\mathrm{CO}_{2}$ absorption unit consisted of a bubble column with a ceramic sparger located at its bottom. The system was operated indoors at the Department of Chemical Engineering and Environmental Technology (University of Valladolid, Spain) for 225 days at average temperature of $23 \pm 2^{\circ} \mathrm{C}$. The HRAP cultivation broth was continuously mixed by a 6-blade paddlewheel at an internal recirculation velocity of approximately $20 \mathrm{~cm} \mathrm{~s}^{-1}$. The surface of the HRAP was continuously illuminated 
at $75 \pm 5 \mu \mathrm{mol} \mathrm{s} \mathrm{s}^{-1} \mathrm{~m}^{-2}$ of average irradiation using 15 Gro-Lux fluorescent lamps (Sylvania, Germany). Despite Shriwastav and Bose (2015) reported that intermittent illumination of 12-h light and dark periods at a light intensity of $246 \mu \mathrm{mol} \mathrm{m} \mathrm{m}^{-2} \mathrm{~s}^{-1}$ ( $\approx$ light saturation threshold for most microalgae species) was the most optimal strategy for sustainable algal-growth indoors, the continuous irradiation used in this particular research likely counterbalanced the low light irradiations used. Likewise, the successful results reported by Serejo et al. (2015) in a similar experimental set-up and at slightly higher light irradiances $\left(104 \pm 25 \mu \mathrm{mol} \mathrm{m}^{-2} \mathrm{~s}^{-1}\right)$ and light:dark cycles of $16: 8 \mathrm{~h}$ showed the sufficient microalgae-bacteria activity at the above mentioned light irradiation. Therefore, the low and continuos light irradiances here used did not invalidate the main outcomes and experimental findings of this study. Effluent sedimentation was carried out in a $8 \mathrm{~L}$ settler operated at $9 \pm 1 \mathrm{~h}$ of hydraulic retention time (HRT) and located at the outlet of the HRAP (Bahr et al. 2014).

\section{Figure 1}

Operational conditions, sampling procedure and calculations

Six different operational conditions were tested in order to simultaneously optimize both $\mathrm{CO}_{2}$ and nutrient removal from simulated biogas and diluted centrates, respectively, and the lipid content of microalgae. Based on these varied objectives, the achievement of an optimum microalgae growth along with the maximization of $\mathrm{CO}_{2}$ removal in the $\mathrm{AC}$ and of lipid accumulation in the algal biomass was difficult. Therefore, the operational conditions were selected in order to obtain a balance for the target objectives. The HRT in the HRAP was maintained constant at 7 days during the entire experimental period, which corresponds to the optimum range for wastewater treatment in HRAPs (3-8 d) (Arbid et al. 2013; Posadas et al. 2015), while simulated biogas was sparged at $38.7 \pm 1.0 \mathrm{~L} \mathrm{~d}^{-1}$ co-currently with an external recycling of algal cultivation broth drawn from the HRAP (at $1.1,3.5$ or $9.9 \mathrm{~m}^{3} \mathrm{~m}^{-2} \mathrm{~h}^{-1}{ }^{1}$ or at their corresponding flow rate expressed in $\mathrm{L} \mathrm{d}^{-1}$ of $34.8,112.2$ or 321.2 depending on the operational stage) (Fig. 1). The simulated biogas flow rate was chosen according to the results reported by Bahr et al. (2014) during the treatment of seven times diluted centrates at $23 \mathrm{~d}$ of HRT in a similar experimental set-up. Centrate dilution was maintained at 1:30 from stages I to IV and increased to 1:70 in stages V and VI in order to limit nutrient supply to the HRAP and to promote lipid accumulation due to the fact that nitrogen starvation has been reported as a successful strategy to increase the lipid content in microalgae cells (Toledo-Cervantes et al., 2013). The areal carbon, nitrogen and phosphorus loads supplied with the wastewater (and with the simulated biogas) ranged from 5.2 to $5.9 \mathrm{~g} \mathrm{C} \mathrm{m}^{-2} \mathrm{~d}^{-1}, 0.2$ to $0.6 \mathrm{~g} \mathrm{~N} \mathrm{~m}^{-2} \mathrm{~d}^{-1}$ and 0.02 to $0.05 \mathrm{~g} \mathrm{P} \mathrm{m}^{-2} \mathrm{~d}^{-1}$, respectively (Table 2). The $\mathrm{pH}$ of the cultivation broth, diffuser pore size in the absorption column and external liquid recirculation flow rate were modified throughout the different operational stages in order to increase the $\mathrm{CO}_{2}$ mass transfer from the gas to the cultivation broth, and consequently the overall C/N/P ratio available for microalgae growth and lipid accumulation (Park et al. 2011). Thus, the $\mathrm{pH}$ of the cultivation broth was increased from 8.5 to 9.5 in stage II via automatic $\mathrm{NaOH}$ addition at $2 \% \mathrm{v} / \mathrm{v}$ (Table 2). Similarly, the pore diameter of the diffuser was decreased from $10 \mu \mathrm{m}$ (porous glass diffuser) to $2 \mu \mathrm{m}$ (metallic diffuser) in stage III. On the other hand, the external recirculation flow rate between the $\mathrm{CO}_{2}$-AC and the HRAP was maintained at $1.1 \mathrm{~m}^{3} \mathrm{~m}^{-2} \mathrm{~h}^{-1}$ in the first 
three stages, and increased to $3.5 \mathrm{~m}^{3} \mathrm{~m}^{-2} \mathrm{~h}^{-1}$ in stage IV and $\mathrm{V}$, and to $9.9 \mathrm{~m}^{3} \mathrm{~m}^{-2} \mathrm{~h}^{-1}$ in stage VI, which entailed an increase in the liquid/gas (L/G) recirculation ratio from 0.9 to 2.9 and 8.3, respectively (Table 2). All the tested conditions were maintained until the steady state was reached, which corresponded to $\approx 4-5$ times the elapsed HRT.

\section{Table 2}

Gas sampling $(100 \mu \mathrm{L})$ was performed twice a week at the inlet and outlet of the $\mathrm{CO}_{2}-\mathrm{AC}$ in order to monitor $\mathrm{CO}_{2}, \mathrm{O}_{2}$ and $\mathrm{N}_{2}$ concentrations (Fig. 1). Similarly, the inlet and outlet gas flow rates were also measured to accurately determine $\mathrm{CO}_{2}$ removal. Liquid sampling was also carried out twice a week by drawing $300 \mathrm{~mL}$ from the wastewater influent and effluent in the HRAP (Fig. 1) to monitor the concentrations of total organic carbon (TOC), inorganic carbon (IC), total nitrogen (TN), $\mathrm{NH}_{4}{ }^{+}, \mathrm{NO}_{2}{ }^{-}$, $\mathrm{NO}_{3}{ }^{-}$, soluble phosphorus $\left(\mathrm{P}_{\mathrm{s}}\right.$ ), total suspended solids (TSS), volatile suspended solids (VSS) and $\mathrm{pH}$. Likewise, liquid samples of $300 \mathrm{~mL}$ were drawn from the cultivation broth twice a week to monitor IC, TSS and VSS concentrations. TOC, IC, TN, $\mathrm{NH}_{4}{ }^{+}, \mathrm{NO}_{2}{ }^{-}, \mathrm{NO}_{3}{ }^{-}$and $\mathrm{P}_{\mathrm{S}}$ concentrations corresponded to the soluble phase, and required liquid sample filtration through $0.20 \mu \mathrm{m}$ nylon filters prior to analysis.

The parameters daily measured were ambient and cultivation broth temperatures, dissolved $\mathrm{O}_{2}$ concentration (DO) in the cultivation broth and the influent and effluent wastewater flow rates, while light intensity at the HRAP surface was weekly monitored. Biomass harvesting was performed every 10 days by centrifugation of the biomass settled at the bottom of the sedimentation tank (Fig. 1).

The removal efficiency (RE) of $\mathrm{CO}_{2}$ in the $\mathrm{AC}$ from the simulated biogas was quantified as follows:

$$
\mathrm{RE}_{\mathrm{CO}_{2}}=\frac{C_{\mathrm{CO}, \mathrm{IN}} \cdot \mathrm{F}_{\mathrm{IN}}-C_{\mathrm{CO} 2, \mathrm{OUT}} \cdot \mathrm{F}_{\mathrm{OUT}}}{C_{\mathrm{CO} 2, \mathrm{IN}} \cdot \mathrm{F}_{\mathrm{IN}}} \cdot 100
$$

Where $\mathrm{C}_{\mathrm{CO} \text {,IN }}$ and $\mathrm{C}_{\mathrm{CO} 2 \text {,OUT }}$ are the concentration (\%) of $\mathrm{CO}_{2}$ in the inlet and outlet biogas in the $\mathrm{CO}_{2}-\mathrm{AC}$, respectively, while $F_{I N}$ and Fout represent the inlet and outlet biogas flow rate $\left(\mathrm{L} \mathrm{d}^{-1}\right)$, respectively. Likewise, the overall carbon removal efficiency was determined according to equation (2):

$$
\mathrm{RE}_{\mathrm{C}}=\frac{\left(\mathrm{C}_{\mathrm{IN}} \cdot \mathrm{Q}_{\mathrm{IN}}+\mathrm{C}_{\mathrm{C}-\mathrm{CO} 2, \mathrm{IN}} \cdot \mathrm{F}_{\mathrm{IN}}\right)-\left(\mathrm{C}_{\mathrm{OUT}} \cdot \mathrm{Q}_{\mathrm{OUT}}+\mathrm{C}_{\mathrm{C}-\mathrm{CO} 2, \mathrm{OUT}} \cdot \mathrm{F}_{\mathrm{OUT}}\right)}{\left(\mathrm{C}_{\mathrm{IN}} \cdot \mathrm{Q}_{\mathrm{IN}}+\mathrm{C}_{\mathrm{C}-\mathrm{CO} 2, \mathrm{IN}} \cdot \mathrm{F}_{\mathrm{IN}}\right)} \cdot 100
$$

Where $\mathrm{C}_{\mathrm{IN}}$ and $\mathrm{C}_{\mathrm{OUT}}$ stand for the concentration of total dissolved C (TOC + IC) in the influent and effluent wastewater $\left(\mathrm{mg} \mathrm{L}^{-1}\right)$, respectively, and $\mathrm{Q}_{\mathrm{IN}}$ and $\mathrm{Q}_{\mathrm{Out}}$ for the influent and effluent wastewater flow rates in the $\mathrm{HRAP}\left(\mathrm{L} \mathrm{d}^{-1}\right)$. In this particular calculation, $\mathrm{C}_{\mathrm{C}-\mathrm{CO} \text {,IN }}$ and $\mathrm{C}_{\mathrm{C}-\mathrm{CO} \text {,Out }}$ were expressed in $\mathrm{mg} \mathrm{C}$ $\mathrm{CO}_{2} \mathrm{~L}^{-1}$.

TOC, IC, TN and $\mathrm{P}_{\mathrm{s}}$ removal efficiencies were also estimated as follows:

$$
\mathrm{RE}_{\mathrm{i}}=\frac{\mathrm{C}_{\mathrm{i}, \mathrm{IN}} \cdot \mathrm{Q}_{\mathrm{IN}}-\mathrm{C}_{\mathrm{i}, \mathrm{OUT}} \cdot \mathrm{Q}_{\mathrm{OUT}}}{\mathrm{C}_{\mathrm{i}, \mathrm{IN}} \cdot \mathrm{Q}_{\mathrm{IN}}} \cdot 100
$$

Where $\mathrm{C}_{\mathrm{i}, \mathrm{N}}$ and $\mathrm{C}_{\mathrm{i} \text {,OUT }}$ correspond to, respectively, the influent and effluent concentrations ( $\mathrm{mg} \mathrm{L}^{-1}$ ) of the target monitored parameter $i$ (TOC, IC, TN or $\mathrm{P}_{\mathrm{s}}$ ). 
The suspended solid removal efficiency of the settler $\left(\mathrm{RE}_{\mathrm{settler}}\right)$ was calculated using the equation (4):

$R E_{\text {settler }}=\frac{T S S_{H R A P}-T S S_{\text {effluent }}}{T S S_{\text {HRAP }}} \cdot 100$

Where TSS $\mathrm{TRAP}_{\text {and }} \mathrm{TSS}_{\text {effluent }}$ stand for the TSS concentration $\left(\mathrm{g}\right.$ TSS L ${ }^{-1}$ ) in the HRAP and in the effluent, respectively. In this context, biomass productivity $\left(\mathrm{W}, \mathrm{g} \mathrm{m}^{-2}\right.$ surface HRAP $\mathrm{d}^{-1}$ ) was quantified according to equation (5):

$W=\frac{T S S_{H R A P} \cdot Q_{\text {out }}}{S}$

where $S$ represents the total HRAP illuminated surface.

Analytical procedures

The gas $\mathrm{CO}_{2}, \mathrm{~N}_{2}$ and $\mathrm{O}_{2}$ concentrations were determined using a Varian CP-3800 gas chromatograph (Palo Alto, USA) equipped with a thermal conductivity detector, a CP-Molsieve 5A $(15 \mathrm{~m} \times 0.53 \mathrm{~mm} \times$ $15 \mu \mathrm{m})$ and a CP-Pora BOND Q $(25 \mathrm{~m} \times 0.53 \mathrm{~mm} \times 15 \mu \mathrm{m})$ columns. The concentrations of dissolved TOC, IC, and TN were measured using a Shimadzu TOC-VCSH analyzer (Japan) coupled with a TNM-1 chemiluminescence module. $\mathrm{N}-\mathrm{NH}_{4}{ }^{+}$concentration was determined with an $\mathrm{NH}_{3}$ specific electrode Orion Dual Star (Thermo Scientific, The Netherlands). The concentrations of N-NO${ }_{3}{ }^{-}, \mathrm{N}-\mathrm{NO}_{2}{ }^{-}$and $\mathrm{P}-\mathrm{PO}_{4}{ }^{3-}$ were quantified by HPLC-IC according to De Godos et al. (2009). The concentration of soluble phosphorus was determined spectrophotometrically using the ammonium molybdate method (Spectrophotometer U2000, Hitachi, Japan). All analyses, including TSS and VSS, were conducted based on Standard Methods (Eaton et al. 2005). The pH of the algal broth was on-line analysed using a R305 Consort system (Belgium), while a Eutech Cyberscan pH 510 (Eutech instruments, The Netherlands) was used for pH determination in the HRAP influent and effluent. Temperature and dissolved oxygen concentration were determined using an OXI 330i oximeter (WTW, Germany). The photosynthetic active radiation (PAR) was measured with a LI-250A light meter (LI-COR Biosciences, Germany).

The algal-bacterial biomass harvested in the settler was dried for 24 hours at $105{ }^{\circ} \mathrm{C}$ prior to characterization. The lipid content of the algal-bacterial biomass was determined gravimetrically following biomass extraction with a chloroform: methanol (2:1 v/v) solution (Kochert, 1978). The determination of the $\mathrm{C}$ and $\mathrm{N}$ content of the algal-bacterial biomass was conducted in a LECO CHNS-932 analyzer, while phosphorus content was determined spectrophotometrically after acid digestion in a microwave based on the internal procedure of the Instrumental Technical Laboratory of Valladolid University according to Standard Methods (Eaton et al., 2005). The identification, quantification and biometry measurements of the microalgae population were performed by microscopic examination (OLYMPUS IX70, USA) of biomass samples (fixed with lugol acid at $5 \%$ and stored at $4{ }^{\circ} \mathrm{C}$ prior to analysis) according to Sournia (1978).

\section{Results}


Temperature, evaporation losses and DO concentrations in the cultivation broth of the HRAP remained constant during the six operational stages $\left(21-22^{\circ} \mathrm{C}, 4-6 \mathrm{~L} \mathrm{~m}^{-2} \mathrm{~d}^{-1}\right.$ and 6-8 $\mathrm{mg} \mathrm{O}_{2} \mathrm{~L}^{-1}$, respectively) (Table $3)$.

\section{Table 3}

Stage I involved the start-up of the HRAP and was characterized by a $\mathrm{RE}_{\mathrm{CO} 2}$ of $47 \pm 9 \%$ (Fig. 2).

\section{Figure 2}

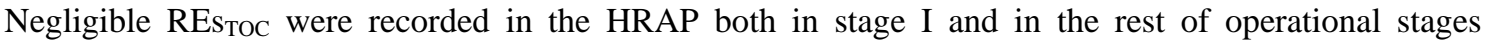
evaluated, despite effluent TOC concentrations remained low (ranging from $14 \mathrm{mg} \mathrm{C} \mathrm{L}^{-1}$ in stage I to 4 mg C L $\mathrm{L}^{-1}$ in stage V) (Table 3). The $\mathrm{RE}_{\mathrm{IC}}$ and $\mathrm{RE}_{\mathrm{C}}$ achieved during stage $\mathrm{I}(54 \pm 6 \%$ and $44 \pm 7 \%$, respectively) represented the highest removal efficiencies along the $225 \mathrm{~d}$ of operation, and entailed the lowest IC concentration $\left(47 \pm 6 \mathrm{mg} \mathrm{C} \mathrm{L}^{-1}\right)$ in the cultivation broth. On the other hand, the $\mathrm{RE}_{\mathrm{TN}}$ and $\mathrm{RE}_{\mathrm{Ps}}$ were $99 \pm 1 \%$ and $74 \pm 7 \%$, respectively, resulting in negligible nitrogen concentrations $\left(0.3 \pm 0.3 \mathrm{mg} \mathrm{L}^{-1}\right)$ in the HRAP and in $\mathrm{P}_{-} \mathrm{PO}_{4}{ }^{3-}$ effluent concentrations of $1.7 \pm 0.4 \mathrm{mg} \mathrm{L}{ }^{-1}$. N-NH${ }^{+}$was completely removed both in stage I and the rest of operational stages (Table 3).

The lowest biomass productivity, TSS concentration in the culture broth and $\mathrm{RE}_{\text {settler }}\left(1.3 \pm 0.2 \mathrm{~g} \mathrm{~m}^{-2} \mathrm{~d}^{-1}\right.$, $0.11 \pm 0.06 \mathrm{~g} \mathrm{~L}^{-1}$ and $66.4 \pm 4.0 \%$, respectively) were recorded during this start-up period. The $\mathrm{C}, \mathrm{N}$ and $\mathrm{P}$ content of the algal-bacterial biomass in stage I was $43.5 \%, 7.9 \%$ and $1.0 \%$, respectively (Table 4).

\section{Table 4}

The predominant Microspora sp. present in the inoculum was gradually replaced by Pseudanabaena minima during stage I, which also coexisted with Scenedesmus and Limnothrix mirabilis, each representing $15 \%$ of the total population (Fig. 3).

\section{Figure 3}

The lipid content of the harvested biomass in stage I decreased from $7.4 \pm 2.1 \%$ (in the inoculum) to $4.6 \pm 2.8 \%$ (Table 4).

Once nitrogen was depleted in the cultivation broth under steady state $\mathrm{I}$, the $\mathrm{pH}$ of the cultivation broth was increased from 8.5 to 9.5 in order to enhance $\mathrm{CO}_{2}$ transfer from the biogas to the liquid phase in stage

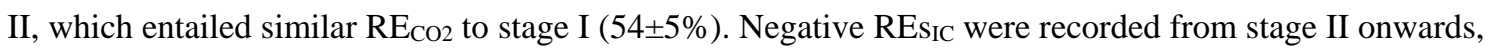
which led to a significant IC concentration increase in the growth medium to $144 \mathrm{mg} \mathrm{L}^{-1}$ in stage II (Fig. 2). Similarly, $\mathrm{RE}_{\mathrm{C}}$ also decreased during stage II to $25 \pm 7 \%$ (Table 4). On the other hand, the $\mathrm{RE}_{\mathrm{TN}}$ during stage II accounted for $66 \pm 7 \%$, with TN effluent concentrations of $7 \pm 2 \mathrm{mg} \mathrm{TN} \mathrm{L}^{-1}$ (which corresponded to nitrate concentrations). $\mathrm{RE}_{\mathrm{Ps}}$ in stage II decreased to $48 \pm 5 \%$, with an effluent concentration of $1.4 \pm 0.3 \mathrm{mg}$ $\mathrm{L}^{-1}$ (Table 4). Biomass productivity and suspended solids concentration in the HRAP increased to 5.4 \pm 0.2 $\mathrm{g} \mathrm{m}^{-2} \mathrm{~d}^{-1}$ and $0.39 \pm 0.10 \mathrm{~g}^{\mathrm{TSS}} \mathrm{L}^{-1}$, respectively, while $\mathrm{RE}_{\mathrm{settler}}$ was $98.2 \pm 1.2 \%$. C, $\mathrm{N}$ and $\mathrm{P}$ biomass content in stage II was 35.6\%, 5.9\% and 1.6\%. During stage II, Chroococcidiopsis sp. was the predominant microalgae in the HRAP, while Microspora sp. was again identified at similar abundances to 
Synechocystis aquatilis (11.2\% and $9.4 \%$, respectively). The lipid content of the algal-bacterial biomass in stage II $(5.2 \pm 2.1 \%)$ was similar to stage I.

A similar $\mathrm{RE}_{\mathrm{CO} 2}(48 \pm 4 \%)$ to previous stages was recorded when decreasing the diffuser pore size in stage III in order to increase the mass transfer area, which was expected to bring about an enhanced $\mathrm{RE}_{\mathrm{CO} 2}$ according to Fick's equation $D=K_{a} \cdot a \cdot \Delta C$ (Bird et al. 2006). The $\mathrm{RE}_{\mathrm{C}}$ in this stage was $20 \pm 4 \%$, while IC concentration in the HRAP remained similar to the previous stage. The RE $\mathrm{TN}_{\mathrm{TN}}$ decreased to $40 \pm 2 \%$, which entailed the highest TN concentrations in the HRAP broth $\left(21 \pm 2 \mathrm{mg} \mathrm{L}^{-1}\right)$, while $\mathrm{REPs}_{\mathrm{Ps}}$ remained constant at 51 $\pm 5 \%$, resulting in $\mathrm{P}_{\mathrm{s}}$ concentration of $2 \mathrm{mg} \mathrm{L}^{-1}$. Biomass productivity and concentration in the algal pond decreased in stage III to $3.9 \pm 0.9 \mathrm{~g} \mathrm{~m}^{-2} \mathrm{~d}^{-1}$ and $0.25 \pm 0.06 \mathrm{~g} \mathrm{~L}^{-1}$, respectively, while a $100 \%$ $\mathrm{RE}_{\text {settler }}$ was recorded (Table 3). The $\mathrm{C}, \mathrm{N}$ and $\mathrm{P}$ biomass content during stage III was 38.5\%, 6.5\% and $1.4 \%$, respectively (Table 4). Synechocystis aquatilis was the predominant microalga in this period, with Microspora sp. and Pseudanabaena minima present at similar proportions. The lipid content increased to $8.9 \pm 3.2 \%$ during stage III, which constituted the maximum value recorded.

An increase in the liquid recirculation from 1.1 to $3.5 \mathrm{~m}^{3} \mathrm{~m}^{-2} \mathrm{~h}^{-1}$ in stage IV (corresponding to a $\mathrm{L} / \mathrm{G}$ increase in the $\mathrm{AC}$ from 0.9 to 2.9) resulted in an enhancement in $\mathrm{RE}_{\mathrm{CO} 2}$ up to $84 \pm 4 \%$ without increase in the $\mathrm{O}_{2}$ concentration in the upgraded biogas (Fig. 4).

\section{Figure 4}

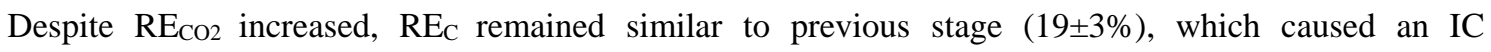
concentration increase to $222 \pm 15 \mathrm{mg} \mathrm{L}^{-1}$. $\mathrm{RE}_{\mathrm{TN}}$ increased to $57 \pm 3 \%$, while $\mathrm{RE}_{\mathrm{Ps}}$ and $\mathrm{P}_{\mathrm{s}}$ concentration were similar to stage III $\left(45 \pm 10 \%\right.$ and $1.7 \pm 0.5 \mathrm{mg} \mathrm{L}^{-1}$, respectively). The biomass productivity and TSS concentration in the HRAP during stage IV slightly decreased to $3.4 \pm 0.2 \mathrm{~g} \mathrm{~m}^{-2} \mathrm{~d}^{-1}$ and $0.22 \pm 0.01 \mathrm{~g} \mathrm{~L}^{-1}$, respectively, with a $\mathrm{RE}_{\text {settler }}$ of $95.5 \pm 1.5 \%$ (Table 3 ). The $\mathrm{C}, \mathrm{N}$ and $\mathrm{P}$ biomass composition was similar to previous stages $(40.1 \%, 7.1 \%$ and $1.3 \%$, respectively). Synechocystis aquatilis (67\%) was again the predominant microalgae. Microspora sp. almost disappeared, while Pseudanabaena minima increased its predominance to $33 \%$ of cells (Fig. 3). The lipid content decreased to $4.1 \pm 1.0 \%$.

Centrate dilution was increased to 1:70 during stage $\mathrm{V}$ in order to induce the nitrogen starvation conditions required for lipid accumulation. $\mathrm{RE}_{\mathrm{CO} 2}, \mathrm{RE}_{\mathrm{C}}$ and $\mathrm{IC}$ concentrations of $82 \pm 2 \%, 22 \pm 1 \%$ and $211 \pm 6 \mathrm{mg} \mathrm{L}^{-1}$, respectively, were recorded. The lower nutrient load implied an increase in $\mathrm{RE}_{\mathrm{TN}}$ to $70 \pm 6 \%$ and a decrease in the effluent $\mathrm{TN}$ concentration to $5 \mathrm{mg} \mathrm{N} \mathrm{L}^{-1}$. Similarly, $\mathrm{RE}_{\mathrm{Ps}}$ increased to $53 \pm 12 \%$ with a concomitant decrease in $\mathrm{P}_{\mathrm{s}}$ effluent concentration to $0.7 \pm 0.1 \mathrm{mg} \mathrm{L}^{-1}$. Despite the lower nutrient load applied, biomass productivity and TSS concentration remained similar at $4.4 \pm 1.0 \mathrm{~g} \mathrm{~m}^{-2} \mathrm{~d}^{-}$ ${ }^{1}$ and $0.29 \pm 0.03 \mathrm{~g} \mathrm{~L}^{-1}$, respectively, with a complete biomass removal in the settler (Table 3). Similarly to previous operational stages, the $\mathrm{C}, \mathrm{N}$ and $\mathrm{P}$ biomass composition was $42.5 \%, 6.2 \%$ and $1.6 \%$, respectively. Pseudanabaena minima was identified as the dominant taxon (92\% of cells). A slightly higher lipid content of $7.4 \pm 0.4 \%$ was achieved during stage V (Table 4).

The increase in the external liquid recirculation to $9.9 \mathrm{~m}^{3} \mathrm{~m}^{-2} \mathrm{~h}^{-1}$ (L/G of 8.3 in the AC) in stage VI resulted in $\mathrm{RE}_{\mathrm{CO} 2}$ up to $99 \pm 0 \%$, and entailed an increase in the $\mathrm{O}_{2}$ concentration of the upgraded biogas 
from $2.1 \pm 1.2 \%$ to $20.7 \pm 0.1 \%$ (Fig. 4). Despite a slightly high increase in $\mathrm{RE}_{\mathrm{C}}$ to $27 \pm 6 \%$ was recorded, the IC concentration in the effluent increased to $228 \pm 15 \mathrm{mg} \mathrm{L}^{-1}$. A complete $\mathrm{TN}$ removal was achieved in stage VI, which supported the occurrence of nitrogen deprivation conditions. Likewise, the high $\mathrm{RE}_{\mathrm{Ps}}$ $(82 \pm 3 \%)$ recorded resulted in the lowest $\mathrm{P}_{-} \mathrm{PO}_{4}{ }^{3-}$ concentrations in the HRAP $\left(0.2 \mathrm{mg} \mathrm{L}{ }^{-1}\right)$. Biomass productivity and TSS concentration remained at $3.6 \pm 0.1 \mathrm{~g} \mathrm{~m}^{-2} \mathrm{~d}^{-1}$ and $0.23 \pm 0.02 \mathrm{~g} \mathrm{~L}^{-1}$, respectively, with a $\mathrm{RE}_{\text {settler }}$ of $97 \%$ (Table 4). C, N and P composition corresponded to 43.6\%, 7.5\% and 1.4\%, respectively. Finally, microalgae population during stage VI was characterized by a high biodiversity. Despite Limnothrix mirabilis was the dominant species (57\%), Geitlerinema sp., Synechocystis aquatilis and Woronichinia sp. were present at similar cell proportions $(\approx 12-15 \%)$. The lipid content of the algalbacterial biomass decreased to $3.3 \pm 0.7 \%$, which represented the lowest recorded value.

\section{Discussion}

Evaporation rate in the HRAP was similar to outdoors systems $\left(\approx 2-7 \mathrm{~L} \mathrm{~m}^{-2} \mathrm{~d}^{-1}\right.$ depending on the geographical area and the HRAP operational conditions; Guieysse et al. 2013; Murphy and Allen 2011) due to the high turbulence in the pond mediated by motor oversizing typical of lab or pilot scale systems (Mendoza et al. 2013). This high cultivation broth turbulence, together with the in-situ $\mathrm{O}_{2}$ produced by microalgae, maintained DO at $6-8 \mathrm{mg} \mathrm{L}^{-1}$, well above the $\mathrm{O}_{2}$ half saturation constant for organic matter oxidation and nitrification ( $\geq 2 \mathrm{mg} \mathrm{O}_{2} \mathrm{~L}^{-1}$ ) (Metcalf and Eddy 2003). Likewise, this high turbulence avoided that algal cells remained long periods of time in the dark.

The estimated dissolved $\mathrm{CO}_{2}$ concentration in the liquid phase was calculated based on the $\mathrm{pH}$ and IC concentration in the cultivation broth of the HRAP and on the $\mathrm{CO}_{2}$ aqueous equilibrium (Metcalf and Eddy, 2003):

$\mathrm{CO}_{2}(\mathrm{l})+\mathrm{H}_{2} \mathrm{O}(\mathrm{l}) \leftrightarrow \mathrm{H}_{2} \mathrm{CO}_{3} \leftrightarrow \mathrm{HCO}_{3}{ }^{-}+\mathrm{H}^{+} \leftrightarrow \mathrm{CO}_{3}{ }^{2-}+2 \mathrm{H}^{+}$[pKa1 $\left(\mathrm{H}_{2} \mathrm{CO}_{3} \leftrightarrow \mathrm{HCO}_{3}{ }^{-}\right)=6.35 ; \mathrm{pKa} 2$ $\left.\left(\mathrm{HCO}_{3}{ }^{-} \leftrightarrow \mathrm{CO}_{3}{ }^{2-}\right)=10.33\right]$

According to these calculations, the estimated dissolved $\mathrm{CO}_{2}$ concentration in the liquid phase decreased from 0.44 (stage I) to approximately $0.03 \mathrm{mg} \mathrm{L}^{-1}$ when the $\mathrm{pH}$ was increased to 9.5 in stage II. This tiny decrease in the dissolved $\mathrm{CO}_{2}$ concentration in the bulk aqueous phase when $\mathrm{pH}$ was increased did not result in significant enhancements in the $\mathrm{CO}_{2}$ concentration gradient from the $\mathrm{CO}_{2}$ aqueous equilibrium in the column (the $\mathrm{CO}_{2}$ gradient increased from $433.6 \pm 9.3 \mathrm{mg} \mathrm{L}^{-1}$ to $434.0 \pm 8.2 \mathrm{mg} \mathrm{L}^{-1}$ ) and consequently in $\mathrm{RE}_{\mathrm{CO} 2}$ in the $\mathrm{CO}_{2}-\mathrm{AC}$ (Fig. 5a/5b). The estimated $\mathrm{CO}_{2}$ equilibrium concentration in the liquid phase in the $\mathrm{AC}$ was calculated using the ideal gas equation and a Henry's adimensional constant of 0.83 at $20^{\circ} \mathrm{C}$ (Sander, 1999), which resulted in a $\mathrm{CO}_{2}$ equilibrium concentration of $\approx 434 \mathrm{mg} \mathrm{CO}_{2} \mathrm{~L}^{-1}$ (Fig. 5a/5b). Similarly, the decrease in the diffuser pore size (which entailed higher gas-liquid interfacial areas), did not result in enhancements of $\mathrm{RE}_{\mathrm{CO} 2}$ due to the higher influence of the liquid recirculation flow rate on $\mathrm{CO}_{2}$ removal as discussed below. In this context, the superior biogas upgrading at higher external liquid recirculation rates was likely due to the higher net $\mathrm{CO}_{2}$ absorption in the algal-bacterial recycling broth since $\mathrm{CO}_{2}$ mass transfer to the aqueous phase did not limit the upgrading process during stages I to III. On the other hand, the oxygen content in the upgraded biogas increased at increasing the liquid recirculation rate above $3.5 \mathrm{~m}^{3} \mathrm{~m}^{-2} \mathrm{~h}^{-1}$, at concentrations well above regulatory limits in most European legislations for biomethane injection in natural gas grids $(\leq 0.3 \%)$ (BOE 2013). This high $\mathrm{O}_{2}$ content in the biogas at stage 
VI would entail potential explosion hazards. In this context, the presence of high $\mathrm{H}_{2} \mathrm{~S}$ concentrations in the biogas and its rapid oxidation in the absorption column, together with the application of further operational strategies in this innovative biogas upgrading technology (e. g. feeding raw centrate or wastewater to the AC to deplete the $\mathrm{O}_{2}$ present in the microalgal recycling stream via organic matter mineralization), are expected to lower these $\mathrm{O}_{2}$ concentrations (Bahr et al. 2014; Serejo et al., 2015). The almost complete removal of $\mathrm{CO}_{2}(99 \pm 0 \%)$ at a $\mathrm{L} / \mathrm{G}$ ratio of 8.3 was higher than the $\mathrm{RE}_{\mathrm{CO} 2}$ reported by Serejo et al. (2015) $(\approx 80 \%)$ at a $\mathrm{L} / \mathrm{G}$ ratio of 10 , which was determined as the optimum to achieve $100 \%$ of $\mathrm{H}_{2} \mathrm{~S}$ removal and $\mathrm{O}_{2}$ concentrations in the treated biogas of $\approx 1 \%$. In addition, it must be highlighted that the energy cost associated to the external recirculation was negligible compared to the energy requirements for mixing in the HRAPs (Bahr et al. 2014). Finally, it should be stressed that solubilization and biological oxidation of $\mathrm{CH}_{4}$ would be expected when upgrading real biogas. However, preliminary tests carried out in our laboratory with simulated biogas showed average $\mathrm{CH}_{4}$ losses of $\approx 1 \%$ (on mass basis) and a negligible effect of $\mathrm{CH}_{4}$ on algal population activity (Serejo et al., 2015).

\section{Figure 5}

The main causes underlying the negative $\mathrm{REs}_{\text {TOC }}$ recorded during the six operational stages were the low concentration and poor biodegradability of the dissolved organic carbon in the diluted centrates fed to the HRAP (Table 1) and the likely presence of TOC released by microalgal metabolism or TOC corresponding to biomass lysis (Posadas et al. 2013; Bahr et al., 2014; Dong et al., 2014; Serejo et al., 2015). At this point it should be stressed that any photosynthetic biogas-upgrading system is a net bioconverter of dissolved inorganic carbon into particulate organic carbon, and the active lysis of this structural organic carbon (often 10-15\% of the new microalgae biomass produced) generates significant amounts of dissolved recalcitrant organic carbon in the form of algal cell debris. On the other hand, the positive $\mathrm{CO}_{2}$ concentration gradient established between the bulk liquid phase $\left(\mathrm{CO}_{2(\mathrm{I})}=0.44 \mathrm{mg} \mathrm{CO} \mathrm{L}^{-1}\right)$ and the atmosphere $\left(\mathrm{CO}_{2}{ }^{*}(\mathrm{I})=0.38 \mathrm{mg} \mathrm{CO}_{2} \mathrm{~L}^{-1}\right)$ promoted $\mathrm{CO}_{2}$ removal by stripping in stage I, since only $17 \pm 6 \%$ of the total carbon removed was recovered in the harvested biomass. The estimated aqueous $\mathrm{CO}_{2}$ concentration in equilibrium with the atmosphere was also calculated using the ideal gas equation and a Henry's adimensional constant of 0.83 at $20^{\circ} \mathrm{C}$ (Sander, 1999), which resulted in an equilibrium concentration of $\approx 0.38 \mathrm{mg} \mathrm{CO}_{2} \mathrm{~L}^{-1}$ (Fig. $5 \mathrm{c} / 5 \mathrm{~d}$ ). However, the high $\mathrm{pH}$ value imposed from stage II onward compared to the reported optimum values of 8 for algal growth of 7-9 for wastewater treatment in HRAPs (Acién et al., 2012; Posadas et al., 2015) mediated $\mathrm{CO}_{2}$ absorption from the atmosphere $\left(\mathrm{CO}_{2(1)}\right.$ $\approx 0.03 \mathrm{mg} \mathrm{CO} \mathrm{L}^{-1}$ from stage II onwards) and prevented $\mathrm{CO}_{2}$ removal by stripping, despite the higher IC concentrations present in the cultivation broth (Fig. 5c/5d). Indeed, the total carbon recovered in the harvested biomass from stage II onward accounted for $100 \pm 5 \%$ of the total $\mathrm{C}$ removed in the HRAP.

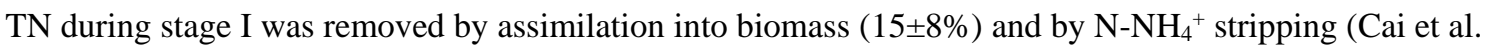
2013; De Godos et al. 2009). Despite pH was increased to 9.5 from stage II onward, $85 \pm 2 \%$ of the TN removed was recovered in the harvested biomass. In this context, the complete $\mathrm{N}-\mathrm{NH}_{4}{ }^{+}$removal and the high nitrification activity supported by the high $\mathrm{N}^{-\mathrm{NO}_{3}}{ }^{-}$effluent concentrations at all operational stage (Table 3), indicated that $\mathrm{N}^{-\mathrm{NH}_{4}}{ }^{+}$oxidation by nitrifying bacteria was faster that $\mathrm{N}^{-\mathrm{NH}_{4}}{ }^{+}$volatilization. Similar results were obtained when treating raw domestic wastewater in an algal turf scrubber 
photobioreactor at HRTs of 5-10d (Posadas et al. 2013). As a matter of fact, the RE $\mathrm{TN}_{\mathrm{N}}$ decrease during stages II and III was correlated to the increase in $\mathrm{N}_{-} \mathrm{NO}_{3}^{-}$concentration (which prevented $\mathrm{NH}_{4}^{+}$ volatilization). On the other hand, the higher IC availability could have mediated the slight increase in TN removal as a result of an enhanced biomass growth at stage IV, while the lower N loads supplied from stage $\mathrm{V}$ onward resulted in the higher $\mathrm{RE}_{\mathrm{TN}}$ recorded. An increase in nitrification activity as a result of the higher IC availability was ruled out based on the steady decrease in nitrate concentration from stage IV onward.

$\mathrm{RE}_{\mathrm{Ps}}$ also showed a significant increase compared to stages II, III and IV when centrate dilution was increased. Phosphorus assimilation into biomass was the main removal mechanism during the six operational stages, with $98 \pm 3 \%$ of the total removed $\mathrm{P}_{\mathrm{s}}$ recovered in the harvested biomass (Cai et al. 2013). Phosphorus did not limit microalgae growth, which occurs at $P_{\mathrm{s}}$ concentrations below $0.2 \mathrm{mg} \mathrm{L}^{-1}$.

The fact that the increase in $\mathrm{RE}_{\mathrm{CO} 2}$ did not result in higher biomass productivities was caused by the low nutrient loads fed into the system in order to increase biomass lipid content. Thus, these biomass productivities (maximum productivity of $5.4 \pm 0.2 \mathrm{~g} \mathrm{~m}^{-2} \mathrm{~d}^{-1}$ in stage II), which could be increased by increasing the nutrient loads, were significantly lower than the typical productivities reported in outdoors HRAPs $\left(\approx 15-20 \mathrm{~g} \mathrm{~m}^{-2} \mathrm{~d}^{-1}\right)$ (Chisti 2007). Nitrogen deprivation was the selected strategy to increase microalgae lipid content, which resulted in the low biomass productivities recorded. However, a balance between biomass lipid content and biomass productivity should be targeted in real scale applications (Feng et al., 2011). The enhanced biomass settleability $\left(\approx 100 \% \mathrm{RE}_{\mathrm{settler}}\right)$ achieved at the highest biomass concentrations $\left(\geq 0.22 \mathrm{~g} \mathrm{TSS} \mathrm{L}^{-1}\right)$ were in agreement with the findings of Park et al. (2011b). In this context, microalgae-based wastewater treatment with effective biomass harvesting by settling represent a cost-effective alternative for algal biomass reutilization compared to conventional physical-chemical techniques such as centrifugation or coagulation/flocculation (De Godos et al. 2011).

Similar C, N and P biomass contents were recorded during the $225 \mathrm{~d}$ of experimentation regardless of the different $\mathrm{C}$ and nutrient load applied, which confirms the constant composition of the algal-bacterial biomass cultivated in wastewater (Posadas et al. 2013). The $\mathrm{C}, \mathrm{N}$ and $\mathrm{P}$ biomass contents were in agreement with those reported by Dominguez-Cabanelas et al. (2013) (C: 43-56\%; N:2-9\%; P: 1.4\%).

A high microalgae biodiversity was found regardless of the operational conditions tested. However, no significant correlation between cultivation conditions and the predominant microalgae species was clearly elucidated. The open design of the HRAP, together with the variations in characteristics of the fed diluted centrate, likely explained the high biodiversity and the rapid changes in the population structure (Devi et al. 2012). These results confirmed the difficulty to maintain monoalgal species in open photobioreactors treating wastewaters (De Godos et al. 2009; García et al. 2000; Serejo et al., 2015).

The lipid content of the algal-bacterial biomass remained low despite the different carbon and nutrient supply strategies evaluated. The lipid contents obtained (2.9 -11.2\%) were in the low reported range in axenic microalgae cultures (5-77\%, Chisti 2007), but were similar to those values reported in microalgae cultivated in wastewaters (2-23\%, Serejo et al., 2015; Sepúlveda et al., 2015). Contrary to previous findings (Toledo-Cervantes et al. 2013), nitrogen depletion in stages I and VI did not result in higher 
biomass lipid contents. The higher carbon availability during stages II and III compared to the start-up period likely resulted in an increase in biomass lipid content. Unfortunately, these contents were not sufficient to sustain a cost-effective wastewater to biodiesel process ( $\approx 30-40 \%$; Chisti 2007). This might be explained by the fact that only few of the species found in the HRAP are lipid producers in moderate contents. In this context, despite Scenedesmus sp. has been reported as the most efficient producer of lipids suitable for biodiesel among the identified microalgae, its abundance in the HRAP was low and only limited to stage I (Mandal and Mallick 2012). The low light irradiances could have also contributed to the poor biomass lipid accumulation in this preliminary proof of concept study under nutrient limitation, since some authors have reported an enhanced lipid synthesis at increasing light irradiances (without reaching photosaturation conditions) under nitrogen limited microalgae growth (Klok et al. 2013; Kandilian et al., 2014). In this context, the biomass here harvested could be used for other purposes than for biodiesel production. Among the potential uses of this residual algal biomass are biofertilization, feedstock for the production of bioethanol and/or biogas (depending on its respective protein and carbohydrate contents) (Romero García et al., 2012; Hernández et al., 2015; Collet et al., 2011; Wang et al., 2013). Despite the natural variation of solar irradiation, $\mathrm{n}^{\mathrm{o}}$ of sun hours and temperature is likely to hinder a fair comparison among the different experimental stages, a further evaluation of this technology must be carried out under outdoors conditions based on the promising results for biogas upgrading and wastewater treatment here reported.

In brief, a complete $\mathrm{CO}_{2}$ removal from biogas was achieved at liquid recirculation rates of $9.9 \mathrm{~m}^{3} \mathrm{~m}^{-2} \mathrm{~h}^{-1}$, which confirms the potential of this technology to photosynthetically upgrade biogas based on residual nutrients from anaerobic digesters. Assimilation into biomass represented the main $\mathrm{N}$ and $\mathrm{P}$ removal mechanisms at $\mathrm{pH} 9.5$ regardless of the operational conditions. Biomass composition remained constant despite the rapid dynamics in microalgae population structure. The HRAP also supported an efficient biomass-effluent separation by settling (>95\%). Finally, the low lipid content (2.9-11.2\%) recorded throughout the different operational stages (even under nutrient limitation), showed the technical difficulty of developing cost-effective wastewater treatment to biodiesel processes and the harvested biomass could be applied for other profitably uses such as biofertilizers or bioethanol and biogas production.

\section{REFERENCES}

Acién FG, Fernández JM, Magán JJ, Molina E (2012) Production cost of a real microalgae production plant and strategies to reduce it. Biotechnol Adv 30:1344-1353

Alam F, Date A, Rasjidin R, Mobin S, Moria H, Baqui A (2012) Biofuel from algae-Is it a viable alternative? Procedia Engineering 49:221-227 DOI:10.1016/j.proeng.2012.10.131 
Arbid Z, Ruiz J, Álvarez-Díaz P, Garrido-Pérez C, Barragán J, Perales JA (2013) Effect of pH control by means of flue gas addition on three different photo-bioreactors treating urban wastewater in longterm operation. Ecol Eng 57:226-235 DOI:10.1016/j.ecoleng.2013.04.040

Bahr M, Díaz I, Domínguez A, González-Sánchez A, Muñoz R (2014) Microalgal-biotechnology as a platform for an integral biogas upgrading and nutrient removal from anaerobic effluents. Environ Sci Technol 48:573-581

Bird RB, Stewart W, Lightfoot EN (2006) Transport Phenomena. 2nd Edition. Ed. Limusa.

BOE (Boletín oficial del Estado), 2013.https://www.boe.es/diario_boe/txt.php?id=BOE-A-2013-185 (Last accessed: 22.09.2014)

Breuer G, Lamers PP, Martens DE, Draaisma RB, Wijffels RH (2012) The impact of nitrogen starvation on the dynamics of triacylglycerol accumulation in nine microalgae strains. Bioresour Technol 124: $217-226$

Cai T, Park SY, Li Y (2013) Nutrient recovery from wastewater streams by microalgae: Status and prospects. Renew. Sust Energ Rev 19:360-369 DOI:10.1016/j.rser.2012.11.030

Chisti Y (2007) Biodiesel from microalgae. Biotechnol Adv 25:294-306

Christenson L, Sims R. (2011) Production and harvesting of microalgae for wastewater treatment, biofuels and bioproducts. Biotechnol Adv 29:686-702

Collet P, Hélias A, Lardon L, Ras M, Goy R A, Steve J P (2011) Life-cycle assessment of microalgae culture coupled to biogas production. Bioresour Technol 102:207-214

De Godos I, Blanco S, García-Encina PA, Becares E, Muñoz R (2009) Long-term operation of high rate algal ponds for the bioremediation of piggery wastewaters at high loading rates. Bioresour Technol 100:4332-4339 DOI:10.1016/j.biortech.2009.04.016

De Godos I, Guzmán HO, Soto R, García-Encina P, Becares E, Muñoz R, Vargas VA (2011) Coagulation/flocculation-based removal of algal-bacterial biomass from piggery wastewater treatment. Bioresour Technol 102:923-927

Devi MP, Swamy YV, Mohan SV (2013) Nutritional mode influences lipid accumulation in microalgae with the function of carbon sequestration and nutrients supplementation. Bioresour Technol 142:278-286 DOI:10.1016/j.biortech.2013.05.001

Dominguez Cabanelas IT, Ruiz J, Arbib Z, Alexandre C, Garrido-Pérez C, Rogalla F, Nascimiento IA, Perales JA (2013) Comparing the use of different domestic wastewaters for coupling microalgal production and nutrient removal. Bioresour Technol 131:429-436 DOI:10.1016/j.biortech.2012.12.152

Dong B, Ho N, Ogden K, Arnold R G (2014) Cultivation of Nannochloropsis salina in municipal wastewater or digester centrate. Ecotox Environ Safe 103:45-53

Eaton AD, Clesceri LS, Greenberg AE (2005) Standard methods for the examination of water and wastewater. 21 st edition. American Public Health Association/American Water Works Association/ Water Environment Federation

Feng D, Chen Z, Xue S, Zhang W (2011) Increased lipid production of the marine oleaginous microalgae Isochrysis zhangjiangensis (Chrysophyta) by nitrogen supplement. Bioresour Technol 102:67106716 
García J, Hernández MM, Mujeriego R (2000) Influence of phytoplankton composition on biomass removal from high-rate oxidation lagoons by means of sedimentation and spontaneous flocculation. Water Environ Res 72:230-237

González C, Marciniak J, Villaverde S, García-Encina PA, Muñoz R (2008) Microalgae-based processes for the biodegradation of pretreated piggery wastewaters. Appl Microbiol Biotechnol 80:891-898

Guieysse B, Béchet Q, Shilton A (2013) Variability and uncertainty in water demand and water footprint assessments of fresh algae cultivation based on case studies from five climatic regions. Bioresour Tecnhol 128:317-323

Hernández D, Riaño B, Coca M, García-González M C (2015) Saccharification of carbohydrates in microalgal biomass by physical, chemical and enzymatic pre-treatments as a previous step for bioethanol production. Chem Eng J 262:939-945 DOI:10.1016/j.cej.2014.10.049

Heubeck S, Craggs R J, Shilton A (2007) Influence of $\mathrm{CO}_{2}$ scrubbing from biogas on the treatment performance of a high rate algal pond. Water Sci Technol 55 (11):193-200

Kandilian R, Pruvost J, Legrand J, Pilon L (2014) Influence of light absorption rate by Nannochloropsis oculata on triglyceride production during nitrogen starvation. Bioresour Technol 163:308-319

Klok AJ, Martens DE, Wijffels R, Lamers PP (2013) Simultaneous growth and neutral lipid accumulation in microalgae. Bioresour Technol 134:233-243

Kochert G (1978) Handbook of phycological methods. London: Cambridge University Press

Mandal S, Mallick N (2012) Biodiesel Production by the Green Microalga Scenedesmus obliquus in a Recirculatory Aquaculture System. Appl Environ Microbiol 78(16):5929-5934

Mendoza JL, Granados MR, De Godos I, Acién FG, Molina E, Banks C, Heaven S (2013) Fluid-dynamic characterization of real scale raceway reactors for microalgae production. Biomass Bioenerg 54: 267-275 DOI:10.1016/j.biombioe.2013.03.017

Metcalf, Eddy (2003) Wastewater Engineering and Reuse, 4th ed., New York, Mc. Graw Hill

Muñoz R, Guieysse B (2006) Algal-bacterial processes for the treatment of hazardous contaminants: a review. Water Res 40:2799-2815

Murphy CF, Allen DT (2011) Energy-water nexus for mass cultivation of algae. Environ Sci Technol 45: 5861-5868

Norsker NH, Barbosa MJ, Vermuë MH, Wijffels RH (2011) Microalgal production: a close look at the economics. Biotechnol Adv 29: 24-27

Park JBK, Craggs RJ, Shilton AN (2011) Wastewater treatment high rate algal ponds for biofuel production. Bioresour Technol 102:35-42

Park JBK, Craggs RJ, Shilton AN (2011b) Recycling algae to improve species control and harvest efficiency from a high rate algal pond. Water Res 45(20): 6637-6649

Posadas E, García-Encina PA, Soltau A, Domínguez A, Díaz I, Muñoz R. (2013) Carbon and nutrient removal from centrates and domestic wastewater using algal-bacterial biofilm bioreactors. Bioresour Technol 139:50-58

Posadas E, Morales MM, Gómez C, Acién FG, Muñoz R (2015) Influence of pH and $\mathrm{CO}_{2}$ source on the performance of microalgae-based secondary domestic wastewater treatment in outdoors pilot raceways. Chem Eng J 265:239-248 DOI:10.1016/j.cej.2014.12.059 
Romero García J M, Guzmán J L, Moreno J C, FernándezSevilla J M (2012) Filtered Smith Predictor to control $\mathrm{pH}$ during enzymatic hydrolisis of microalgae to produce L-aminoacids concentrates. Chem Eng Sci 82:121-131

Sander R (1999) Compilation of Henry's Law Constants for Inorganic and Organic Species of Potential Importance in Environmental Chemistry; http://www.mpch-mainz.mpg.de/ sander/res/henry.html, 1999. (Last accessed: 20.03.2015)

Sepúlveda C, Acién F G, Gómez C, Jiménez Ruiz N, Riquelme C, Molina-Grima E (2015) Utilization of centrate for the production of the marine microalgae Nannochloropsis gaditana. Algal Res 9:107116 DOI:10.1016/j.algal.2015.03.004

Serejo M L, Posadas E, Boncz M A, Blanco S, García-Encina P A, Muñoz R (2015) Influence of biogas flow rate on biomass composition during the optimization of biogas upgrading in microalgalbacterial processes. Env Sci Technol 49 (50): 3228-3236

Shriwastav A, Bose P (2015) Algal growth in photo-bioreactors: Impact of illumination strategy and nutrient availability. Ecol Eng 77:202-215 DOI: 10.1016/j.ecoleng.2015.01.034

Sournia A (1978) Phytoplanton Manual. Museum National d' Historie Naturelle, París. United Nations Educational. Scientific and Cultural Organization (Unesco)

Toledo-Cervantes A, Morales M, Novelo E, Revah S (2013) Carbon dioxide fixation and lipid storage by Scenedesmus obtusiusculus. Bioresour Technol 130:652-658

Wang X, Nordlander E, Thorin E, Yan J (2013) Microalgal biomethane production integrated in an existing biogas plant: A case study in Sweden. Appl Energ 112:478-484 DOI:

10.1016/j.apenergy.2013.04.087 


\section{FIGURE CAPTIONS}

Figure 1. Schematic diagram of the continuous biogas upgrading and nutrient removal experimental setup. Grey circles represent liquid sampling ports (1: influent, 2: effluent; 3: cultivation broth) and grey squares represent gas sampling ports (1: inlet biogas, 2: upgraded biogas). Continuous lines represent liquid streams and dashed lines represent biogas streams.

Figure 2. Time course of $\mathrm{CO}_{2}$ removal in the absorption column (o) and IC concentration in the cultivation broth $(\bullet)$.

Figure 3. Time course of the microalgae population structure in the HRAP during the six operational

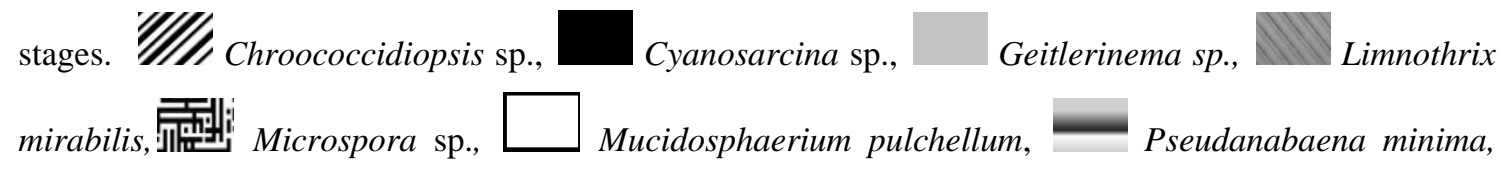
Scenedesmus sp.

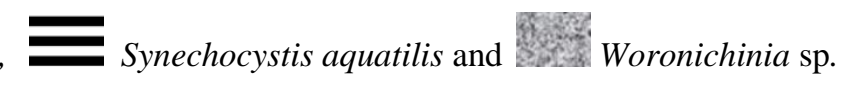

Figure 4. Influence of the liquid recirculation flow rate in the $\mathrm{CO}_{2}-\mathrm{AC}$ on $\mathrm{CO}_{2}$ removal (continuos line) and $\mathrm{O}_{2}$ concentration in the upgraded biogas (discontinuous line).

Figure 5. Estimated $\mathrm{CO}_{2}$ concentration gradients between the biogas and the external recirculating cultivation broth in the AC at a pH of 8.5 (a) and 9.5 (b), and between the cultivation broth in the HRAP and the atmosphere at a $\mathrm{pH}$ of 8.5 (c) and 9.5 (d). 


\section{Figure 1}

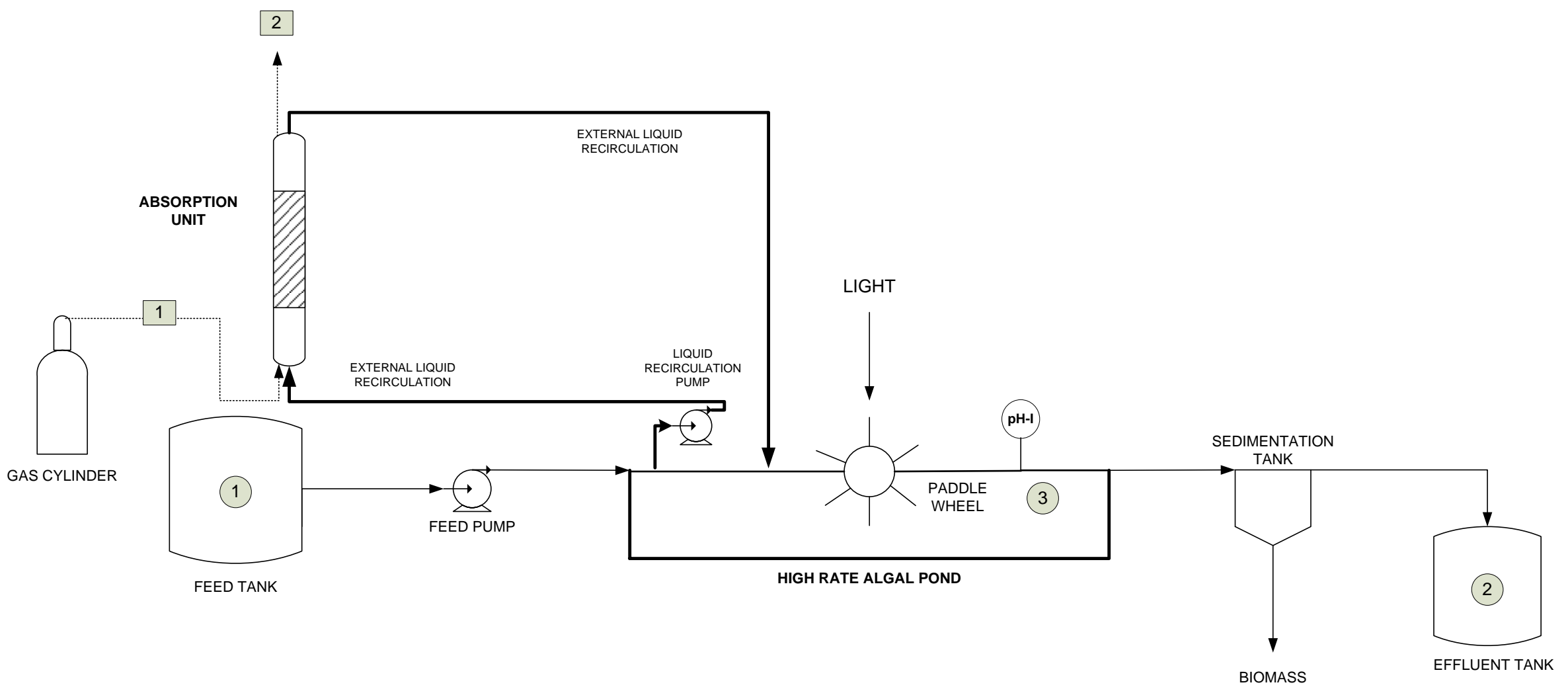


Figure 2

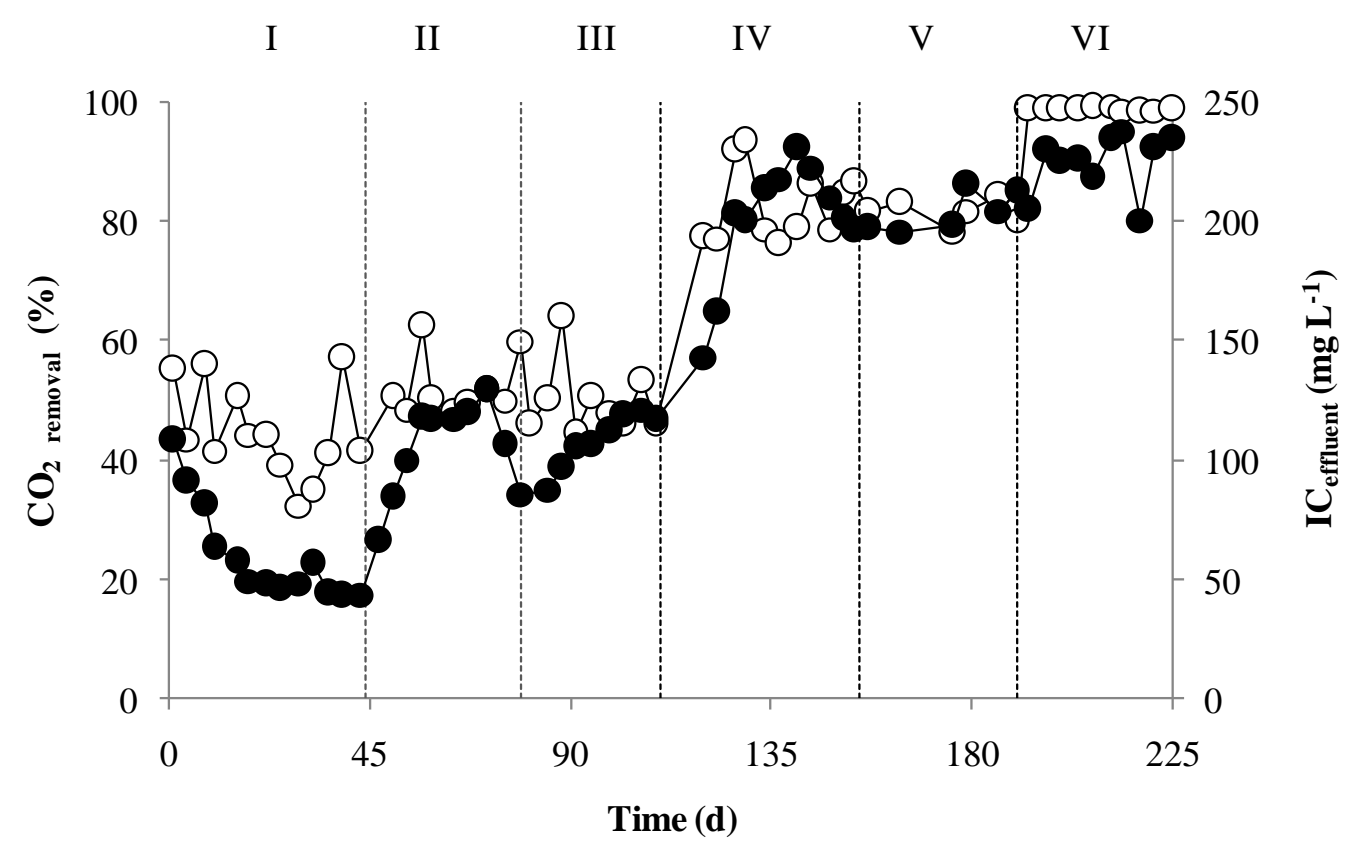


Figure 3

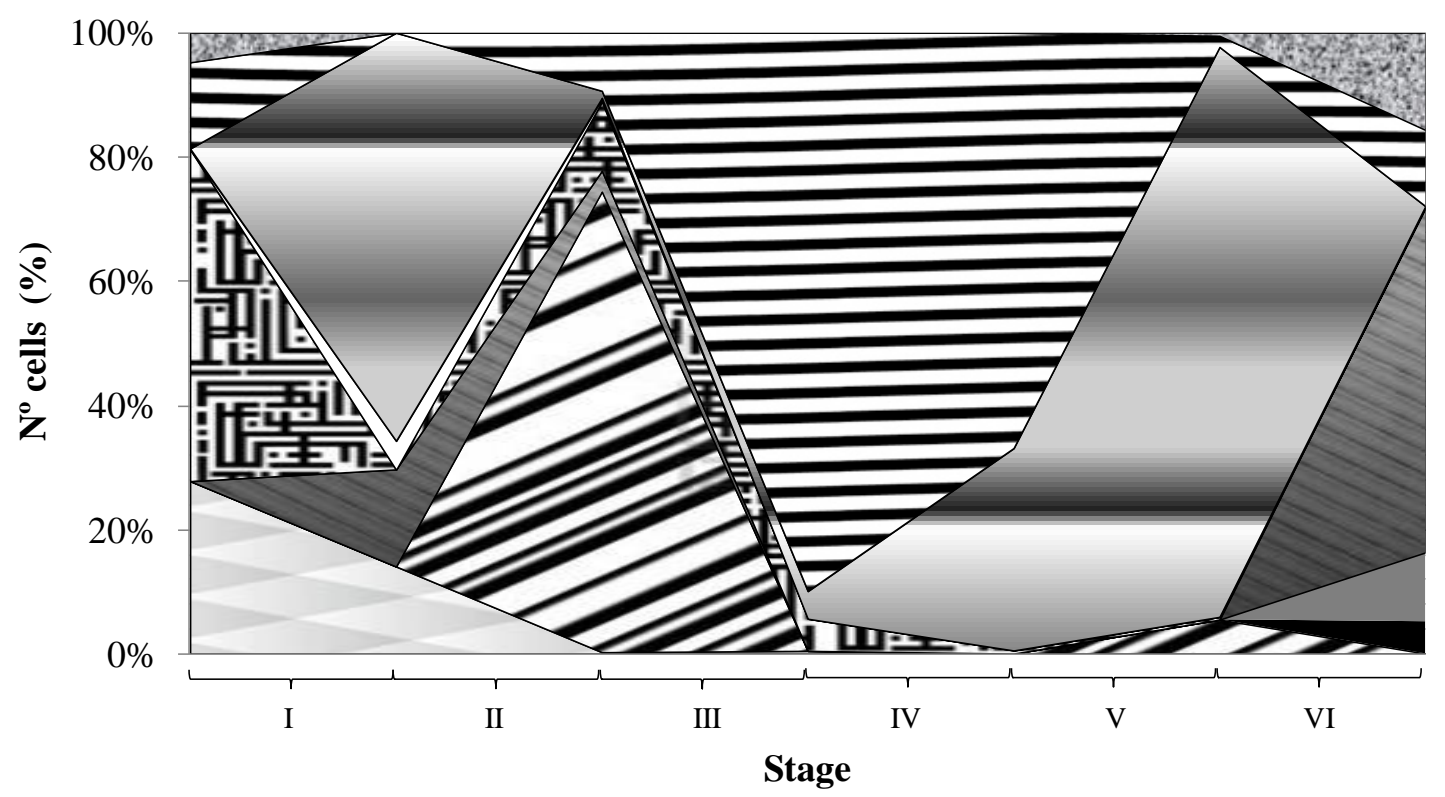


Figure 4

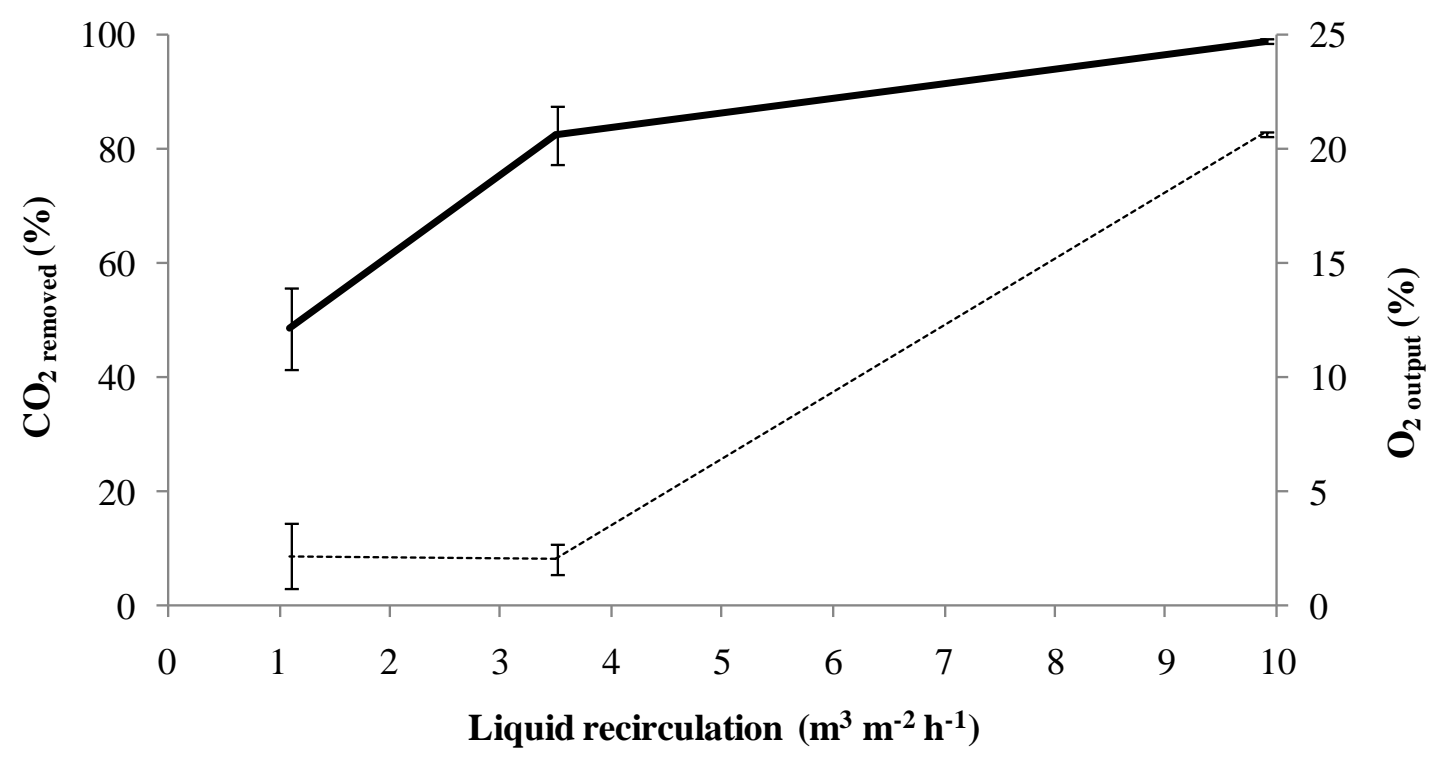


Figure 5

a)

$\mathrm{pH}=8.5$

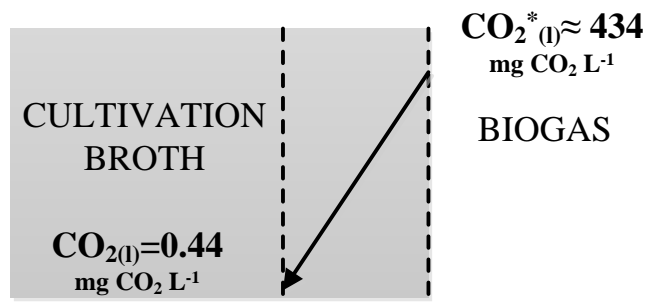

$\mathrm{CO}_{2}$ mass transfer

$\mathrm{CO}_{2}$ gradient:

$433.6 \pm 9.3 \mathrm{mg} \mathrm{CO}_{2} \mathrm{~L}^{-1}$

c)

$\mathrm{pH}=8.5$

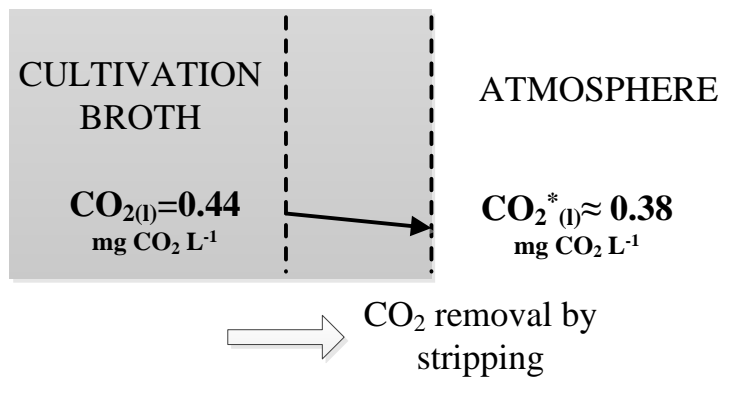

b)

pH=9.5

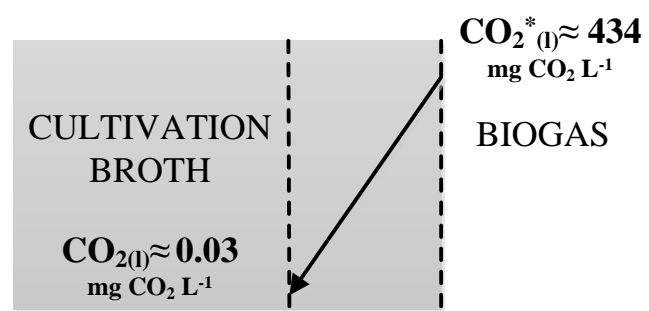

$\mathrm{CO}_{2}$ mass transfer

$$
\mathrm{CO}_{2} \text { gradient: }
$$

$434.0 \pm 8.2 \mathrm{mg} \mathrm{CO}_{2} \mathrm{~L}^{-1}$

d)

pH=9.5

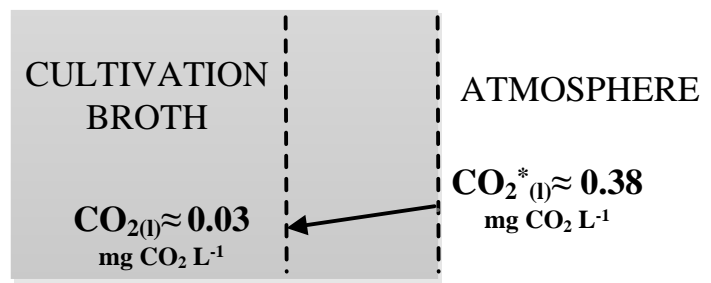

$\mathrm{CO}_{2}$ sequestration IC concentration $\uparrow$ 